\title{
The Act of Killing: Sins Appearing on the Surface of the Crystal-Image
}

\author{
Ziya Ayd1*
}

\begin{abstract}
As one of the critical concepts in Gilles Deleuze's philosophy of cinema, crystal-image makes visible the pure state of time that contains the real and the imaginary, the present and the past, the actual and the virtual in a way that cannot be distinguished from each other. This type of image, in which the virtuality of the past and the actuality of the present coexist, is of great importance in providing an audio-visual context that can be investigated to discover the connection between time and memory.

In this article, firstly, recollection-image and the use of flashback will be discussed considering Deleuze's interpretation of Henri Bergson's views on time and memory, and in connection with this, it will be explained what the crystal-image is. Then, it is aimed to reveal the characteristics of the perfect crystal-image, which is the first of the four types mentioned by Deleuze, through the analysis of The Act of Killing (Joshua Oppenheimer, 2012), which is identified as one of the contemporary examples.

In line with this goal, the self-confrontation of paramilitary gang leader Anwar Congo, who is the main character, through becoming a spectator of his own life due to the manifestation of the pure state of time within the crystal-image, will be explained by analyzing certain scenes selected from the documentary. In addition, the possibility of transmission of the crystallized personal memory to the silver screen independently and objectively from the fictional history that surrounds it will be investigated, and the possible practical benefits of crystal-image will be addressed through the change in the perception of the national and international public opinion regarding the Indonesian mass killings of 1965-1966 after the screening of the documentary.
\end{abstract}

Keywords: Deleuze, crystal-image, memory, time, documentary.

*E-mail: aydiziya@gmail.com

ORCID : 0000-0002-1144-2475

DOI: 10.31122 /sinefilozofi.888216

Aydı, Z. (2021). The Act of Killing: Sins Appearing on the Surface of the Crystal-Image. Sinefilozofi Dergisi, Özel Say1 (3), 211-219. https// doi.org/0000-0002-1144-2475 


\title{
Öldürme Eylemi: Kristal-İmajın Yüzeyinde Beliren Günahlar
}

\author{
Ziya Ayd1*
}

\section{Özet}

Gilles Deleuze'ün sinema felsefesindeki kilit kavramlardan biri olan kristal-imaj; gerçek ile hayali, şu an ile geçmişi, aktüel ile virtüeli birbirlerinden ayırt edilemeyecek şekilde içinde barındıran zamanın saf halini görünür kılmaktadır. Geçmişin sanallığının ve şimdiki zamanın mevcudiyetinin bir arada var olduğu bu imaj çeşidi, zaman ve hafıza arasındaki bağlantıyı keşfetmek adına incelenebilecek görsel-işitsel bir zemin sağlaması açısından büyük önem taşımaktadır.

Bu makalede öncelikle Henri Bergson'un zaman ve hafizaya dair görüşlerinden yola çıkılarak anı-imaj ve flashback kullanımı ele alınacak ve bununla bağlantılı bir şekilde kristal-imajın ne olduğu açıklanacaktır. Ardından Deleuze'ün sözünü ettiği dört kristal türünden ilki olan mükemmel kristalimajın özelliklerinin, güncel örneklerinden biri olarak tespit edilen The Act of Killing (Öldürme Eylemi, Joshua Oppenheimer, 2012) belgeselinin çz̈zümlenmesi aracılığıyla ortaya konulması amaçlanmaktadır.

Bu hedef doğrultusunda belgeselin ana karakteri olan paramiliter çete lideri Anwar Congo'nun; kristal-imajın içindeki yekpare zaman tezahürü sayesinde bir gösteri haline gelen kendi hayatının seyircisine dönüşerek suçlarıla yüzleşme süreci, filmden seçilmiş belirli sahnelerin analiz edilmesiyle açıklanacaktır. Ayrıca kristalleşen kişisel hafızanın kendisini çevreleyen kurgusal tarihten bağımsız ve dolayısıyla objektif bir biçimde sinemaya taşınma imkânı soruşturularak, gösterimi sonrası belgeselin konu edindiği 1965-1966 Endonezya katliamlarıla ilgili ulusal ve uluslararası kamuoyunun algısında gerçekleşen değiş̧im üzerinden kristal-imajın olası pratik faydalarına değinilecektir.

Anahtar Kelimeler: Deleuze, kristal-imaj, hafiza, zaman, belgesel.

*E-mail: aydiziya@gmail.com

ORCID : 0000-0002-1144-2475

DOI: 10.31122 /sinefilozofi.888216

Aydı, Z. (2021). The Act of Killing: Sins Appearing on the Surface of the Crystal-Image. Sinefilozofi Dergisi, Özel Say1 (3), 211-219. https//doi.org/0000-0002-1144-2475

Geliş Tarihi: 28.02.2021

Kabul Tarihi: 10.07 .2021 


\section{Introduction}

Gilles Deleuze gives autonomy to the philosophy of cinema by presenting a system that permits the examination of subjects interrelated with cinema without making them limited to the terms of any other research field. Hence, it is not surprising that his work includes a notion that can be considered to help the research on the relation between memory and time in the context of their way of visualization in films. This is the crystal-image, a subcategory of timeimage conceptualized by Deleuze. It is defined as the unity of an actual image and a virtual image to the point where they can no longer be distinguished (Deleuze, 1989, p. 335).

Before moving on to explain crystal-image in detail, Henri Bergson's theories on time and memory should be explored because Deleuze has used them as the basis while forming the concepts in his philosophy of cinema. Contrary to the common sense understanding, time is not merely the unity of successive moments for Bergson. There is a dynamic relationship between the present and the past in which the formation of time indicates itself. The past is formed in the present, similar to how the perception of an event begins to be transformed into recollection at the moment that event occurs. Deleuze describes this as the fundamental position of time in which the past is contemporaneous with the present that it has been, and he states that the past would never be constituted if it did not coexist with the present (Deleuze, 1991, pp. 58-59). This notion of coexistence of the past and the present leads to another conclusion that the past is also maintained in itself. Bergson's famous inverted cone of memory demonstrates this idea of self-containment of the past (Bergson, 2004, p. 152). The peak of the cone represents the actual present and the contraction of the past within it, while its base refers to the largest circuit between the perception of the present and the recollection of the past. However, since all the other layers between them are expressions of all the virtual pasts always in relation to the actual present, the cone as a whole is the qualitative multiplicity of the past in itself. Then, it would be accurate to say that the past is being in itself that virtually exists, and the present is actual becoming in which this virtual past is perpetually reconstituted to actualize. In this context, Deleuze defines the crystal-image as the indiscernibility of the actual image of the present and the virtual image of the past, which makes visible the split of time in two heterogeneous directions at each moment towards the present and the past (Deleuze, 1986, p. 81).

\section{Recollection-Image and Flashbacks}

For Bergson, memory operates in two ways; first, automatic recognition that is instantaneous and unconscious. He illustrates this with the example of walking in a city. If it is the first time the walking person has been there, then every decision to take a turn from a corner would be affected by hesitation because there is no recollection of the city, which may help recognize the path. After spending enough time in the city, the person automatically recognizes the surroundings even without consciously paying attention to them and finds the way with the help of a sense of familiarity (Bergson, 2004, p. 110). This is the unity of perception and memory in action mechanically habituated by sensory-motor schema.

On the other hand, attentive recognition contains a reflection that puts identical or similar recollection-images of the past upon the present perception to enrich it (Bergson, 2004, pp. 123-124). In this type of recognition, there is a projection of memory on perception, which causes a distance between perception-image and the summoned recollection-image. The size of this distance that Bergson calls "circuit" proportionally increases in attentive recognition related to the intensity of attention on the perceived object. Recollection-images are summoned from a more distant past as the focus of perception on the object amplifies. In this context, the largest circuit, which is the dream, contains all the past, although it is ambiguous. Also, 
every recollection-image emerges from a specific plane of memory that is a circuit constituted between the actual perception and its virtual memory summoned from the past. That is why Deleuze relates recollection-images to the appearance of a new sense of subjectivity. Different from the subjectivity that is brought by affections between perception and action in movement-images which spatially occupies the gap, recollection-image temporally fulfills the gap by leading back and forth from perception to memory (Deleuze, 1986, p. 47). However, recollection-images nevertheless need to be in accord with the linear causality provided by sensory-motor schema. This dependency of them to the chronological time can be most explicitly detected in flashbacks that contain the warning for the involvement of the subjectivity supplied by recollection-images. Flashbacks are used when there is a narrative necessity not to tell the story in the present such as it is a matter of a mystery or a secret.

For example, All About Eve (Joseph L. Mankiewicz, 1950) is a combination of flashbacks that tell the story of Eve from the perspectives of people around her. The progress of Eve's story is given as circuits born into each other. Each circuit, such as meeting Margo, taking her place, trying to steal her lover, blackmailing her friend, has an internal moment to connect them to the next one. Margo sees Eve with her own costume on the stage and gets suspicious; the critic overhears Eve when she is trying to seduce Margo's lover; her friend Karen receives an invitation from Eve for a conversation when she is on the table with others who are the witnesses. As Deleuze points out, these are the testimonies of the birth of a recollection because memory cannot evoke the past if it has not already been constituted at the moment when the past is still present. Memory has been made in the present in order to be used in the future when the present will be the past (Deleuze, 1986, p. 52). Recollection-images actualize a virtual event by confirming the past as the old present, and flashbacks follow the causality conforming to the sensory-motor schema even when they refer to the past. This commitment of recollection-images to the perception is based on the misrepresentation of the memory in a structure that begins from the present and goes back to the past.

For Bergson, memory does not consist in a regression from the present to the past; on the contrary, it takes shape in a progressive manner from the past to the present (Bergson, 2004, p. 319). There is a virtual plane where pure memory ontologically survives in a temporal form independent from any spatiality, and its actualization is a process starting from that plane until its materialization as an image to be fit in the actual perception. This process includes so many different planes of lived experience that recollection must go through step by step. Bergson likens this movement of memory, which separates the subject from the present and replaces it in a certain region of its past, to the focusing of a camera (Bergson, 2004, p. 171).

It is clear that there is an implication related to the nature of time on the ground of the operation of the memory. Deleuze draws attention to it by claiming that the images which are able to present time directly through pure optical and sound situations may arise in conflicts between memory and perception, such as hallucination or déjà-vu because of their incompatibility with the actuality of present (Deleuze, 1986, pp. 54-55). Therefore, what needs to be explained is the realm of that plane in which Bergson claims that the past virtually exists as a whole, unchanged by the different layers of consciousness that recollections encounter as they move towards perception. According to Deleuze, what appears in this virtual plane where the explanation for the inherent productivity of thought pulled away from absolute perception is also concealed, would be the crystal-image as the smallest circuit between the actual and the virtual (Moulard-Leonard, 2008 p. 114). 


\section{The Genesis of Crystal-Image}

As the smallest circuit, the crystal-image has two sides continuously becoming each other through the reciprocal exchange between the real and the imaginary, the present and the past, or the actual and the virtual. It is important to note that this indiscernibility is not derived from the perception of the spectator, but it is based on the nature of the image itself. The best way to demonstrate this objective double-sidedness of the crystal-image is the mirror. There are two sides of the image of an object reflected on a mirror: it becomes virtual on the surface, and its virtual reflection on the surface also becomes actual in relation to the object in front of the mirror. The exchange between the object and its reflection forms the smallest circuit between the actual and the virtual. This image in which an object and its reflection in the mirror coexist gives the simplest state of the crystal. Two films that Deleuze also refers, stand out in terms of their use of mirrors and the way they set preliminary examples for the formation of the crystal-image.

The first example (Deleuze, 1986, p. 70) is from The Lady From Shanghai (Orson Welles, 1947). In its final scene, the confrontation in the magic mirror maze forms an excellent crystalimage where the actuality of the two characters is disrupted by their reflections on multiple mirrors. They shot at these virtual reflections, win their actuality back by breaking them, and eventually kill each other. Another remarkable point in this scene is that the virtuality of the characters, which becomes apparent on the mirrors, is also already distributed to the narrative by keeping their motivations hidden throughout the film. They confess and reveal the mystery just before they murder one another. In this sense, it is possible to argue that each vanishing virtual reflection in the broken mirrors stands for the characters' other potential endings in the film, but the only actuality waiting for them at the end is death.

The final scene of All About Eve can be considered another example of the crystal-image created through mirrors. After winning the prestigious award, Eve encounters Phoebe, who is one of her fans, sneaked into her room before she returns there. Phoebe as the reflection of her early days when Eve met Margo, immediately starts to manipulate just as Eve did earlier. While she rests in the other room, Phoebe holds the award with Eve's glamorous robe on herself and poses in front of the multi pane mirror as an echo of the scene that Eve tries Margo's dress on the stage. As Phoebe's actual image is infinitely reflected in the mirror, she loses her actuality and becomes the virtual image of the common feature of all these characters. She transforms into Eve; Eve transforms into Margo; they all become indiscernible in the eternal recurrence of the search for fame. Phoebe stands there, at the edge of the next line of successful actors, and the image of countless young women literally identical to her actualize on display. They wait for their turn with the same desire in their soul: to be famous actors.

Of course, this is not a coincidence since one of the elements that can be exemplified for the formation of the crystal-image is the relation between the actors and their roles. Deleuze himself claims that the stage becomes a crystal when the actor makes the virtual image of the role actual (Deleuze, 1986, p. 71). The virtual role becomes apparent while the actual image of the actor is left behind. This transformation of the actor while he or she gets in and out of character, has the same structure as the crystal-image since it creates unity where the real and the imaginary, or the actual and the virtual, meet in the same image of the body.

In the broadest sense of the term, reflection stands out as the generic feature of exemplary scenes for the crystal-image, including mimetic enactments (Bogue, 2003, p. 121). Deleuze asserts the use of other artworks in the film as well, from paintings to theatre pieces, songs to 
literary texts for the elements that can be considered as the reflections of the two sides in the crystal-image. In this regard, it is possible to think of intertextuality as one of the methods applied for the formation of the crystal. Likewise, self-reflexivity stands out as one of the modes of the crystal since a film within the film is also capable of rendering the line invisible between the actual and the virtual. Sometimes it is the film that takes itself as its object in the process of its making (Deleuze, 1986, p. 76), and this transforms it into a crystal.

\section{The Act of Killing as Perfect Crystal}

While the typical feature of the element that forms crystal-image is the reflective relationship between the actuality of something and its own virtuality carried in itself, as explained above, Deleuze claims that there can be different states of the genesis of crystal. Although they are open to being diversified, he speaks of four crystalline states: perfect, cracked, growing, and dissolving. Each of these crystalline states makes time visible in a relevant manner and presents a different aspect of it. However, no matter how different these images are, they all have one thing in common: the split of time in two asymmetric streams, one of which makes all the present pass, while the other preserves all the past. Time consists of this split in accordance with the Bergsonian conception, and this is what is seen in the crystal (Deleuze, 1986, p. 81).

As Deleuze declares, what is seen explicitly in the perfect crystal is the time which has already rolled up, rounded itself, at the same time as it was splitting (Deleuze, 1986, p. 84). In this sense, it would not be wrong to say that the perfect crystal also possesses the image of an unavoidable self-confrontation, considering that someone who is in a fully enclosed crystal would see himself or herself everywhere he or she looks. In such a condition, the pressure would be devastating, and there would be no place to escape because the perfection of the crystal does not even allow anything outside of itself to exist.

It is possible to define Joshua Oppenheimer's The Act of Killing as a masterpiece that explores the banality of evil and exposes it to the audience. However, this documentary also sets an excellent example of the perfect crystal. The documentary deals with the Indonesian mass killings in which nearly one million civil people are murdered between 1965-1966 under the accusation of being communists. Oppenheimer's approach is built on the depictions of torture and executions carried out by unpunished perpetrators who still hold the political power in the country. It is exceptionally beyond the conventional narrative because the killers themselves produce the scenes where they reenact their own past crimes, and the making process of these scenes, including the discussions between them about the history and the justification of events, is also shown in the film. Thus, the classic documentary style, for example, in Shoah (Claude Lanzmann, 1985) or Dead Souls (Wang Bing, 2018), in which usually victims are listened to, is turned inside out.

The killers, led by Anwar Congo, a charismatic, energetic and humorous monster, are gangsters who made money by selling movie theatre tickets of Hollywood films on the black market before turning into a paramilitary death squad. In the interviews, the killers say that they have developed the methods of murder and torture by taking inspiration from the Hollywood films they watched in those years, and they re-stage these crimes based on their own memories, in the style of their favorite film genres such as Western, musical and mafia films. In this way, they virtualize again the actual images of their acts in front of the camera, which were initially influenced by virtual scenes from films, and this bewildering transformation forms the smallest circuit between the actual and the virtual. Indiscernibility is especially apparent in the dramatization of the massacre of villagers at Kampung Kolam. After the shooting of this scene, some women and children involved in it as extras are still in shock and can not 
stop crying. The moment when one of the members of the paramilitary organization said to the little girl that she acted great, but now she has to stop crying, is remarkable in this respect. The insensitivity of this person against the crying child points that he has managed to remain unaffected by the crimes he committed through putting himself in place of the characters in the films he watched, that is, through virtualizing himself. Not only what happened in this scene that we saw in the documentary, but probably the actual massacre that occurred years ago for this person was also virtual when it was actually happening. One might also think that the state propaganda against communists played a major role in this. But no matter what, this scene contains important indicators of how a person can continue life without being regretful by the torture and massacres he perpetrated.

The most crucial image revealing the crystal with all its perfection is brought to light in the scene where Anwar Congo confronts his own past. In one of the scenes in which the killers stimulate the cruelty done by themselves, Anwar takes on the role of a tortured communist. While watching this scene with the director Oppenheimer, Anwar has to come face to face with the reality he has been trying to run away from for more than forty years, and he empathizes for the first time with the people he murdered. The actuality of the horrific things he performed in his past crystallizes in the image of the scene on the television screen, which he virtualizes by putting himself in the place of the victim while he originally was the perpetrator. With the help of this image that becomes limpid in the perfect crystal, Anwar's past unfolds in such a way that he can no longer escape its reality.

Oppenheimer's documentary technique in which he completely leaves the control to his subjects, gives a brilliant result in accordance with the nature of the issue he deals with. In order to avoid the confrontation with the consequences of his actions, Anwar is virtually reconstructed his past in his memories through the imagination as if he was the actor in a film. When Oppenheimer encourages to transform this virtuality into actuality with the pretext of making a film, Anwar's past crystallizes within the present and traps him inside. It is no coincidence that The Act of Killing ends with Anwar's retching as a physical reaction against this pure state of time and his own dreadful existence in it.

In this context, Oppenheimer's striking documentary also provides a piece of evidence for the utility of the crystal-image in cinema. Of course, its efficacy is not only limited to make a murderer regretful who killed hundreds of people with his bare hands. The flawless clarity of the image in the perfect crystal is beneficial to objectively illuminate the content of the issues dealt with in documentary films, especially if they have been concealed or deformed for various political or economic reasons throughout history, as in the case of The Act of Killing. It is a fact that the perspective about this communist purge, which has been accepted as a victory by the perpetrators who still politically rule Indonesia, is changed after the film was released (Oppenheimer, 2014). The issue is no longer a completely ignored taboo, and it has been started to be critically evaluated by the Indonesian people, allowing them to confront their historical past. Director Oppenheimer's emphasis on the involvement of the United States of America in the events has also lead to the declassification of related documents and the acceptance of encouragement and support for the mass murder by the US government of that period. Therefore, it is legitimate to argue that making the pure state of time visible by the crystal-image also means liberating the time from the domination of the fictional history written by the winners. 


\section{Conclusion}

Each crystalline state makes time visible in a relevant manner and presents a different aspect of it. Although they are not explored here because they are beyond the scope of this article, cracked crystal emphasizes the relation between time and subjectivity, growing crystal reveals the simultaneity of different sheets of the past, and dissolved crystal presents lateness as a dimension of time. On the other hand, perfect crystal underlines a confrontation with the pure state of time, which is indivisibly concrete. It presents life as a whole with the overwhelming pressure of all past actions on its present, but independent from the fictitious history surrounding it. The characters in the crystal are the spectators of their own spectacle. This self-impression of being revealed simultaneously with all their faults and sins causes psychological or even physical impacts on them since it is very intense.

Apart from disclosing the underlying reality of time, the crystal-image has another significance for the audience. Since the actual and the virtual are intertwined in it, the crystalimage allows multiple interpretations and, therefore, the emergence of thought from a more critical point of view, rather than unconditional acceptance of the given image. Thus, it enables people to review events that have been accepted or imposed without being questioned for a long time from different perspectives. In line with this capacity, the potential benefits of employing the crystal-image in documentaries seem promising, particularly as observed in The Act of Killing.

\section{Conflict of Interest Statement}

The author of the article declared that there is no conflict of interest.

\section{Bibliography}

Bergson, Henri, (2004), Matter and Memory. Mineola: Dover.

Bogue, Ronald, (2003), Deleuze on Cinema. New York: Routledge.

Deleuze, Gilles, (1991), Bergsonism. New York: Zone Books.

Deleuze, Gilles, (1989) Cinema 2: The Time-Image. London: Athlone.

Moulard-Leonard, Valentine, (2008), Bergson-Deleuze Encounters: Transcendental Experience and the Thought of the Virtual. Albany: State University of New York Press.

Oppenheimer, Joshua. (2014, February 25). The Act of Killing has helped Indonesia reassess its past and present. The Guardian. https:// www.theguardian.com/commentisfree/2014/ $\mathrm{feb} / 25 /$ the-act-of-killing-indonesia-past-present-1965-genocide

\section{Filmography}

Lalou, S. (Producer), \& Bing W. (Director). (2018). Dead Souls [Documentary]. France: Les Films d'Ici.

Lanzmann, C. (Producer/Director). (1985). Shoah [Documentary]. France: Les Films Aleph.

Sørensen, S. (Producer), \& Oppenheimer J. (Director). (2012). The Act of Killing [Documentary]. Denmark: Final Cut for Real. 
Welles, O. (Producer/Director). (1947). The Lady from Shanghai [Motion Picture]. United States: Mercury Productions.

Zannuck, D. (Producer), \& Mankiewicz J. (Director). (1950). All About Eve [Motion Picture]. United States: 20th Century Fox. 